\title{
FOREIGN INTERNSHIPS AS A FACTOR OF FOREIGN LANGUAGE TEACHERS' PROFESSIONAL DEVELOPMENT
}

\author{
ESTÁGIOS ESTRANGEIROS COMO FATOR DE DESENVOLVIMENTO \\ PROFISSIONAL DE PROFESSORES DE LÍNGUAS ESTRANGEIRAS
}

\section{PASANTÍAS EN EL EXTRANJERO COMO FACTOR DE DESARROLLO PROFESIONAL DE LOS PROFESORES DE LENGUAS EXTRANJERAS}

\author{
Galina V. Tretyakova1(D), Natalya V. Chernyishkova2 ${ }^{\text {(D) }}$, Rosaria Filone ${ }^{\text {(D) }}$
}

\footnotetext{
${ }^{1}$ Financial University under the Government of the Russian Federation, Moscow, Russian Federation.

${ }^{2}$ Financial University under the Government of the Russian Federation, Moscow, Russian Federation.

${ }^{3}$ Technical Institute "G.Deledda", Lecce, Italy.

Corresponding author:

Galina V. Tretyakova

Email: gvtretyakova@fa.ru
}

How to cite: Tretyakova, G. V., Chernyishkova, N. V., \& Rosaria Filone, R. (2021). Foreign Internships as A Factor of Foreign Language Teachers' Professional Development. Revista Tempos E Espaços Em Educação, 14(33), e15125. https://doi.org/10.20952/revtee.v14i33.15125

\begin{abstract}
The aim of the study is to find ways to expand teacher efficacy by participating in foreign internships. Survey methods were used to collect the data from students. Descriptive statistics was used to examine the overall trends in foreign language teachers' professional development. Thus, passing a training abroad leads to the development and improvement of language, professional, and cultural competencies of not only teachers, but also students; improving the skills of teachers, their motivation; increasing not only the prestige of the educational organization, but also the publication activity of university employees in world scientific publications; improving educational technologies. And most importantly, students, as direct participants of the educational process, are more than satisfied with their results. The article is of interest for the foreign language teachers.
\end{abstract}

Keywords: Organizational culture. Professional learning community. Teacher efficacy. Foreign internships.

\section{RESUMO}

O objetivo do estudo é encontrar formas de expandir a eficácia do professor por meio da participação em estágios no exterior. Métodos de pesquisa foram usados para coletar os dados dos alunos. Estatísticas descritivas foram usadas para examinar as tendências gerais no 
desenvolvimento profissional dos professores de línguas estrangeiras. Assim, passar um estágio no exterior leva ao desenvolvimento e aprimoramento das competências linguísticas, profissionais e culturais não apenas dos professores, mas também dos alunos; melhorar as habilidades dos professores, sua motivação; aumentar não só o prestígio da organização educacional, mas também a atividade de publicação de funcionários universitários em publicações científicas mundiais; melhoria das tecnologias educacionais. E o mais importante, os alunos, como participantes diretos do processo educacional, estão mais do que satisfeitos com seus resultados. $O$ artigo é de interesse dos professores de línguas estrangeiras.

Palavras-chave: Cultura organizacional. Comunidade de aprendizagem professional Eficácia do professor. Estágios no exterior.

\section{RESUMEN}

El objetivo del estudio es encontrar formas de ampliar la eficacia de los docentes mediante la participación en prácticas en el extranjero. Se utilizaron métodos de encuesta para recopilar los datos de los estudiantes. Se utilizaron estadísticas descriptivas para examinar las tendencias generales en el desarrollo profesional de los profesores de lenguas extranjeras. Así, aprobar una formación en el extranjero conduce al desarrollo y mejora de las competencias lingüísticas, profesionales y culturales no solo de los profesores, sino también de los estudiantes; mejorar las habilidades de los profesores, su motivación; aumentar no solo el prestigio de la organización educativa, sino también la actividad de publicación de los empleados universitarios en publicaciones científicas mundiales; mejorar las tecnologías educativas. Y lo más importante, los estudiantes, como participantes directos del proceso educativo, están más que satisfechos con sus resultados. El artículo es de interés para los profesores de lenguas extranjeras.

Palabras clave: Cultura organizacional. Comunidad de aprendizaje profesional. Eficacia docente. Pasantías en el extranjero.

\section{INTRODUCTION}

Increased academic and scientific mobility is a characteristic feature of modern universities. The financial University under the Government of the Russian Federation is not an exception. Every year, a huge number of our students and teachers travel to various countries of the world for scientific and industrial internships, conferences, seminars, studies, etc. This develops cultural and economic ties between states and contributes to general scientific and technological progress. In the past academic year, seven foreign language teachers of the Department of foreign languages and intercultural communication went on internships in the UK, China, the USA and France. Without a doubt, this incomparable experience directly related to the specifics of our profession, a real " upgrade", represents a more valuable opportunity for a foreign language teacher in an authentic environment. Yes, if it is still organized and conducted by experienced teachers with at least 15 years of experience in the field of special training of foreign language teachers.

At the end of the program, all the participants received international certificates confirming their knowledge. In addition, they had the opportunity to improve their skills not only within the course, but also as a result of sharing experience with colleagues from all over the world, joining the international community of foreign language teachers. The participation of teachers from many countries of the world made it possible to exchange views with colleagues on a number of professional issues, as international teams were formed at each seminar, which required the use of competencies necessary for working in an intercultural environment. It should be noted that our teachers were respected by their colleagues and represented our University with dignity in terms of professional and language training. 
Those internships left a bright mark in cultural and educational terms. In addition to useful information obtained during the training process, it allowed our teachers to get experience of staying in the country of the taught language, immerse themselves in its culture and way of life, and expand their horizons. All this, of course, is extremely important, both for improving the professional skills of a foreign language teacher, and for expanding cultural horizons. For example, our teachers were able to feel the spirit of ancient Oxford with its famous Christ Church-where Harry Potter was filmed, visit Stratford-upon-Avon-the birthplace of William Shakespeare, the medieval castle of Warwick and witness a Grand show about the War of the roses in England, between the Lancastrians and the Yorks.

The information received at lectures and seminars of outstanding specialists is undoubtedly discussed and will be discussed at various events of the Department, used in writing articles and methodological materials, and, first of all, directly in student auditoriums.

Since this was not the first participation of foreign language teachers in foreign internships, the purpose of the trips was not only to gain new knowledge and experience, but also to create a decent image of the teaching school of the Financial University, and to show the role of foreign internships in the foreign language teachers' professional development.

\section{LITERATURE REVIEW}

The past decade has seen a tidal wave of proposals to reform education. Seeking to improve what students get from school, reformers advocate changes in standards and assessment, school organization and decision making, and curriculum. The vision of a better education is complex. Teachers are to help diverse learners become competent and skilled, understand what they are doing, and communicate effectively. Schools are to be connected with their communities, and all students are to succeed in ways they currently do not and never have before in the history of public education. If such plans are to move in any significant way beyond rhetoric to permeate practice, significant professional development will be crucial, for such instruction is not commonplace. Nor could teachers change instruction in these ways simply by being told to do so. Teachers would need opportunities to reconsider their current practices and to examine others, as well as to learn more about the subjects and students they teach. Reformers routinely invoke the need for professional development, and there is no shortage of in-service workshops for teachers. Although a good deal of money is spent on teachers' development, most is spent on sessions and workshops (Ball \& Cohen, 2009). Though teacher professional development is essential to efforts to improve our educational institutions (Borko, 2014). That is why it is necessary to overview some important directions and strategies for extending our knowledge into new territory of questions not yet explored.

The most important factor in the quality of students' learning is the quality of teaching and school leadership (Cambridge Professional Development Qualifications, 2018). Teachers and leaders need to develop their professional thinking and practice continuously throughout their careers. Cambridge PDQs have been designed to lead the way in enriching professional learning in schools. These qualifications are based on research evidence about the kinds of professional development that have real impact and value. Cambridge PDQs help practicing teachers and education leaders to:

- engage critically with relevant educational thinking and international best practices

- apply new ideas and approaches in their own practice

- reflect on and share experiences and outcomes to

plan further development

- improve the quality of their students' learning

Multiyear study examines the teaching performance of teachers trained in the professional development school (PDS) compared with teachers trained in a traditional teacher preparation 
program at the same university. Teachers trained in the PDS had higher overall teaching performance than those trained in the traditional program (Richards \& Farrel, 2012). We can say that continuing professional development Richards \& Farrel, 2012) when provided formally, is something that is easy to recognize but perhaps rather more difficult to define. Theoretical and empirical controversy surrounds the scope and understanding of the concept.

By examining information about the nature of professional development opportunities (Darling-Hammond et al., 2019) currently available to teachers and in a variety of contexts, education leaders and policymakers can begin both to evaluate the needs of the systems in which teachers learn and do their work and to consider how teachers' learning opportunities can be further supported.

Fullan, for example, (Fullan, 2011; Fullan \& Miles, 2012) has effectively highlighted major educational change problems which happen in most of the contexts, and he has successfully engaged readers with different aspect by providing insightful and anecdotes. The book is packed with lots of critical information related to change which requires reflecting and relating with our own context to see what actually happens. For those of us focused on educating, researching, helping, and driving school and educational system change, Michael Fullan has filled in as pioneer, guide, and tutor.

As for Michael Garet (Garet et al., 2011), he uses a national probability sample of 1,027 mathematics and science teachers to provide the first large-scale empirical comparison of effects of different characteristics of professional development on teachers' learning. Results, based on ordinary least squares regression, indicate three core features of professional development activities that have significant, positive effects on teachers' self-reported increases in knowledge and skills and changes in classroom practice: (a) focus on content knowledge; (b) opportunities for active learning; and (c) coherence with other learning activities. It is primarily through these core features that the following structural features significantly affect teacher learning: (a) the form of the activity (e.g., workshop vs. study group); (b) collective participation of teachers from the same school, grade, or subject; and (c) the duration of the activity.

Allan A. Glatthorn implemented a special term (Glattenhorn et al., 2017) "Psychology Cooperative Professional Development" is the inclusive term used here to embrace these and other forms of peer-oriented systems. His experience in helping numerous campuses implement such programs. As schools increasingly adopt new technologies in enhancing teaching and learning, models of teacher professional development are also evolving (Guskey, 2010). To ensure that teacher development programmes effectively assist them in integrating technology in instructional processes, a study was conducted to determine a more acceptable model of teacher professional development. This study employed a quantitative survey methodology in the collection of data towards the development of a model on technology integration in classrooms and the identification of training needs for teachers. A total of 400 teachers were selected to participate in this study using the stratified random sampling technique from primary schools in 10 Regions of Cameroon to identify their preferences in a professional development model. The data was analysed using percentages, frequency counts, mean and standard deviation. The results indicated that teacherparticipants showed a strong preference for an on-going school-based professional development model that supports collaborative learning, problem solving and involves classroom follow-up. A review of the weaknesses in current models as well as literature on best practices in in-service teacher training led to the proposed Mastery of Active and Shared Learning Processes for Technopedagogy (MASLEPT) model.

Martin Nystrand (Nystrand \& Gamoran, 2011) examines two kinds of student engagement: "procedural," which concerns classroom rules and regulations; and "substantive," which involves sustained commitment to the content and issues of academic study. It describes the manifestations of these two forms of engagement, explains how they relate differently to student outcomes, and 
offers some empirical propositions using data collected on literature instruction, collected during ten years from 58 eighth-grade English classes ( $N=1,041$ students). The results provide support for the following three hypotheses: (1) disengagement adversely affects achievement; (2) procedural engagement has an attenuated relationship to achievement because its observable indicators conflate procedural and substantive engagement; and (3) substantive engagement has a strong, positive effect on achievement. Features of substantively engaged instruction include authentic questions or questions that have no prespecified answers; uptake or the incorporation of previous answers into subsequent questions; and high-level teacher evaluation or teacher certification and incorporation of student responses in subsequent discussion. Each of these features is noteworthy because it involves reciprocal interaction and negotiation between students and teachers, which is said to be the hallmark of substantive engagement.

Jackson Nzarirwehi (2019) introduced Teacher Development Management Systems, with the sole aim of supporting and enhancing professional development of teachers through in-service teacher training. Though the training has increasingly motivated teachers into upgrading their academic qualifications, research has not established the effect of the training on professional development of teachers and loopholes, assumptions and misconceptions still persist two decades after the inception of the Teacher Management Systems. Using primary data collected in 2016 from the southwestern Uganda districts of Bushenyi, Rukungiri \& Sheema, this study attempts to examine this issue. Key informant interviews and questionnaires were used to collect data from a sample of 610 primary teachers and education stakeholders selected for the study. Findings show that inservice teacher training has a significant effect on teachers, particularly on their academic qualifications, performance, and professionalism. However, these benefits can only be realized when the training is properly planned, implemented and continually evaluated, and in the presence of certain resources and incentives. To this end, the study recommends a review of teacher training approaches and a revamp of educational environments to facilitate the teaching-learning process. Nassira Boudersa adds that (Boudersa, 2016) being competent and well-performing teacher is one of the most important resources in any educational institution. The teacher is considered the professional agent and the most directly responsible person in the process of learning; he is the one in charge of making/helping students learn and benefit or suffer from the quality of his teaching. Given this, the teacher and the quality of his teaching are always under discussion and receive prevalent importance in education. Nowadays, the Algerian educational institutions, for example, like any other educational institutions around the world, is at risk when it comes to the fact that we may encounter a situation whereby our educational systems fail to educate and form excellent learners. As a result of such concerns, there is usually a persistent need in education to assure effective teaching for students at all levels. The call today is for teachers' evaluation procedures as a way to provide assurance in the teaching/learning processes. Teachers are used to come to their career as teachers with little formal professional training or experience. Lack of professional training and professional development of teachers can be a key source for any dissatisfaction in the quality of their teaching to form competent students with the necessary knowledge and skills in the different subject matters. Today, there is a need to shift from traditional-based teaching that is largely based on theoretical educational processes to a research-theory-based teaching that informs and inspires teaching practices.

Results from a study of the relationship between different kinds of professional development supports and early childhood practitioners' use of 10 types of recommended early intervention/early childhood special education practices are reported (Borg, 2018). The participants were 955 practitioners employed in early intervention, preschool, preschool special education, Early Head Start, Head Start, and other early childhood programs in a Midwestern state. The practitioners were asked to indicate if their school districts, agencies, or programs offered and provided (1) information about recommended practices, (2) professional development specialists demonstrated 
the use of the practices for the practitioners, (3) the practitioners were provided opportunities to learn to use the practices, and (4) practitioners were provided coaching and performance feedback. Responses to these four types of professional development supports were used to group practitioners into low, moderate, or high degrees of professional supports. Findings showed that practitioners who reported receiving a combination of all four types of supports reported more frequent use of recommended practices compared to practitioners in the other two groups. Implications for in service professional development are described. Results from a study of the relationship between different kinds of professional development supports and early childhood practitioners' use of 10 types of recommended early intervention/early childhood special education practices are reported. Communication competence, as a system of knowledge, skills, abilities, motivational disposition, attitudes and properties, is the essential competence of teachers (Zaslow, 2014). In the last twenty years teacher communication competence has been one of the most important content of teacher training programmes. However, the effects of teacher communication education have not been investigated systematically; there is not specific comparison of the effects of these programmes between student-teachers and active teachers. Teacher's and studentteacher's communication skills were investigated from 2006 to 2014. The sample consists of student- prospective teachers, prospective subject teachers, and active teachers in Serbia who participated in communication training in the last 5 years. There are differences in some sociocommunication skills between the examined groups. In the process of communication education teacher communication competence is increased, its specific competencies emphasized (social sensitiveness, non-violent verbal communication, integrative style of conflict management, interaction involvement). "Factors Driving Learner Success in Online Professional Development" (Vu et al., 2017). This study examined factors that contributed to the success of online learners in an online professional development course. Research instruments included an online survey and learners' activity logs in an online professional development course for 512 in-service teachers. The findings showed that there were several factors affecting online learners' success in online professional development. In addition, there were also significant differences between successful and unsuccessful online learners in terms of course login frequency and learning activities viewed.

Darling-Hammond et al. (2019) report the results of a three-year capacity building effort to improve core reading knowledge and practice in 165 third-grade teachers working in 63 urban schools and its effects on student reading outcomes. Teachers volunteered to participate in one or two years of professional development lasting from 90 to 180 hours. Core reading knowledge among teachers resulted in statically significant growth with generally large effect sizes. Three cohorts of third-grade students taught by participating teachers were assessed on multiple measures of reading at the beginning and end of each school year. Results for within-year improvement showed large effects on all student outcomes. Analysis of the magnitude of student gains between the three years found that for two of the four measures gains in year one were exceeded in years two and three. Implications for professional training to facilitate improved reading outcomes are discussed.

In our article we consider the role of foreign internships in the foreign language teachers' professional development.

\section{MATERIALS AND METHODS}

During the internship, our teachers received new knowledge on linguodidactics and modern educational materials for courses: the use of mobile devices in the classroom, motivation of lowmotivated students, the development of effective listening skills and key factors in the preparation of creative teachers, modern methods of teaching a foreign language were mastered, an analysis of current trends in the language was conducted, workshops were held in the development of a lesson 
plan using additional resources, multimedia and IT technologies, modeling situations and analyzing typical errors caused by language interference. During the training were also considered:

- a productive approach to teaching a foreign language, in particular, methods of problembased learning, partially-search, research. According to the above methods, students learn to acquire knowledge and skills themselves: the teacher does not give ready-made answers, but prepares a subject and illustrative environment, questions for finding an answer (a rule or method of activity); after "opening" a new one, they are offered consolidation exercises aimed at developing foreign language communicative competence. The search for a new concept, rule, method is carried out by students, work in a group is encouraged, and front-line work is minimized;

- method of organization of classroom classes with newspaper articles for students, aimed at the development of productive speech activity.

1st session: 1) discusses the chronology of events in the last 12 months in the country of the target language (the list of events is proposed by the teacher); 2 ) a list of adjectives describing these events (historical, revolutionary, shocking, unexpected etc.); 3 ) organizes a discussion in a group of 3 people, then to the class)

2nd session: 1) students are asked to analyze the content of the first page different titles according to the questions aimed at the clarification of the potential readers of this publication/newspaper: left, right, liberals, conservatives... 2) organization of discussion material in the pair; 3) representation of the contents of the first page group, discussion in a group; 4) after discussion of the first page the students are offered an exercise on matching the terms of the article with its content

3rd session: 1) students are invited to analyze the full content of the article, according to the questions (open-type questions, multiple choice) developed by the teacher, including key lexical units; 2) discussion in pairs; 3) presentation of the content of the article to the class; 4) discussion in the classroom, comparison with those already presented; 5) fixing the lexical material on the topic under discussion (working with the press);

4th session: 1) students perform exercises to fix the lexical material of the press, filling in the meaning of the gaps in the sentences; 2) make a sentence based on key expressions, names of newspapers/magazines proposed by the teacher; 3 ) listening: viewing news (annotation of all news at the beginning of the programme) with the definition of news without sound; students make assumptions about their content based on what they see; 4) individual work of students, listening to the news chronicle, its independent transcription; 5) checking the dictation in a group / individually (the teacher presents the correct version of the transcription to each student on paper/electronic media). This method of teaching allows students to smoothly immerse themselves in the material, focusing not on translating the material from a foreign language into their native language, but on understanding the content of the original text, developing language guesswork when reading/listening /discussing the material in a foreign language. Thus, an active approach to teaching a foreign language better contributes to the formation of all types of speech activity in a foreign language;

- the most relevant provisions of modern teaching methods, including innovative developments of foreign teachers in the field of teaching foreign languages, based on the Bloom taxonomy;

- mobile applications (training and application) for the development of communicative competence; criteria for selecting training proposals, principles of working with applications; the main methodological problems that arise when using mobile applications.

- a communicative approach to learning, which is manifested, first of all, in the organization of group training of students in various modes, which leads to a significant increase in the level of dynamism of the class. The task of the teacher and students is to learn to work together, to move away from individualized learning. The student learns to listen to their fellow group members, 
conduct conversations and discussions in the group, and work on projects together with other group members. The student focuses more on their group mates than on their teacher as a model. The formation of the competence of one communication participant takes place over the account of communication with other participants. All exercises and tasks are based on communication. Various examples of projects, role-playing and business games, discussions, and even theatrical performances were demonstrated. The teacher does not give lectures or formulate rules using a large number of grammatical terms: they are themselves comprehended by students on the basis of text analysis (that is, using the method of induction, not deduction). The teacher usually acts as an assistant, friend, or adviser. Great importance is attached to the development of paraphrase skills in attempts to explain and express concepts in various ways.

- the most relevant provisions of modern teaching methods, including innovative developments of foreign teachers in the field of teaching foreign languages, based on Peer Assessment technology, when students give a grade for assignments according to the scheme set by the teacher. The final score is the average of the scores awarded by the group members. Variations or additions to mutual evaluation can be: mutual commenting as a statement of his own opinions in the form of recommendations, arguments in continuation of the theme either as a rebuttal to the author of the work (used in the evaluation of works for which it is difficult to formulate clear assessment criteria, and includes a mandatory response to the author of the review); mutual peer review, which involves a detailed and reasoned comment in the review form, based on teacher-defined criteria to work. The teacher determines the impact of mutual assessment on the overall results of training: formulates recommendations and criteria based on which students make reviews and evaluate the work of their fellow students; sets the "weight" of the results of mutual verification of works in the final score for completing the task. The use of this technology means greater involvement of students in the learning process, additional practice in receptive and productive types of speech activity, and increased internal motivation to learning a foreign language, which ultimately contributes to the formation of all kinds of students' competences: a teamwork, which is very important to form an objective assessment, communication - because teamwork involves the development of such qualities of students as the ability to communicate, to listen and hear others, to express and convey their ideas to different people, critical thinking, as it involves an objective and comprehensive discussion of incoming information, and, finally, creativity - because it develops the ability to apply not standard solutions and the ability to create new tools for solving problems;

- advantages of the lexical approach to language teaching in comparison with the grammatical approach. Despite the fact that some aspects of this issue are controversial, and, of course, the level of language teaching at our University provides excellent knowledge of grammar by students, still some arguments in favor of a more extended use of the lexical approach are interesting and the proposed recommendations can be partially applied in the educational process.

As for Italy, students and teachers at all levels are encouraged to experience internships abroad in order to improve their knowledge of foreign languages. Universities and schools recommend academic mobility and encourage their students and teachers to participate in the Erasmus program or to pass a training abroad.

Every year, a large number of Italian students and teachers attend foreign language courses, in particular English courses in the UK and other countries. The duration of these courses can be from one week to one year but and over, in any case, they give the students the opportunity to learn a foreign language living in strict contact with other people from all over the world, in a college or in a family for example, so developing intercultural communication and opening their minds at the same time. Students not only learn a foreign language but they learn also the culture and the habits of the country in which they are having the internship. At the end of these training internships students get certifications recognized in all academic fields. 
Teachers' professional development is highly recommended at all levels in Italian schools. Passing a training abroad gives the teachers the opportunity to improve their knowledge of a foreign language and leads to the development of professional and cultural competencies and skills, thus improving their motivation and the efficacy of their methods. In the UK, for example, many English language teaching organisations, accredited by the British Council, offer a huge number of opportunities to all professionals who want to learn English. One of these organizations is AngloContinental, in Bournemouth, where teachers can pass a training internship to learn more about teaching English. Anglo-Continental is an approved Training Centre for the University of Cambridge Certificate in English Language Teaching to Adults (CELTA). The courses concentrate on methodology and practice rather than on theory. They also show participants how they can extend their skills, practice and effectiveness after completion of the course.

In the last ten years I spent at least two weeks a year in different cities of the UK attending English courses in order to improve my Knowledge of English language. Living in London, Edinburgh, Bournemouth and visiting the English countryside, The Highlands or some of the most famous cities like Oxford and Cambridge, Brighton, Bath, Stratford-upon-Avon, Winchester, is a precious experience from different points of view one should go through once in his life.

My personal exposure at Anglo-Continental in the years 2018/2019 is extremely positive. In the summer $2018 \mathrm{I}$ attended the TKT (Teaching Knowledge Test) COURSE, Modules 1,2,3, taking the exam and getting a certificate. The Teaching Knowledge Test is a test developed by Cambridge ESOL for teachers of English to speakers of other languages. It it designed to test candidates' knowledge of concepts related to language and language use, and the background to and practice of language teaching and learning.

All participants are provided with authentic materials, books, copies, magazines, and and every kind of tools useful for a full immersion in an authentic environment. They are taught to use technological devices to increase the students' motivation and modern methods of teaching a foreign language. In particular, during their internships teachers learn: Language and background to language learning and teaching; lesson planning and use of resources for language teaching; managing the teaching and learning process.

The course tutors are always extremely supportive and understanding of the difficulties one can encounter in learning methodology in a foreign language.

In the summer 2019 I attended the same course to gain new knowledge of English language, thus having a new opportunity to meet people from all over the world (I met Chinese, Russian, Arabic and Japanese teachers), to share with them ideas and experiences on methodology and extending my own culture.

\section{RESULTS}

For the period 2018-2020 academic years, 20 teachers of the Financial University have completed foreign language training in Spain, France, China, the United Kingdom, and the United States in order to improve their foreign language proficiency and expand their didactic knowledge of teaching methods. At the same time, the authors of the article came up with the idea to compare the results of teachers ' work from the point of view of students before and after the internship. A survey was conducted of 1530 students in the groups where these teachers conduct classes.

Students were asked to answer the following questions in the spring before the summer internship and in the winter of the next academic year after passing it:

- able to clearly, easily and consistently present the material;

- connects theoretical knowledge with the practical component of the future profession;

- able to interest and engage the student in the learning process; 
- from the first lesson in the discipline puts forward clear and understandable requirements for evaluating knowledge in classes, certifications and exams; objective in evaluating students ' knowledge and work; interested in improving the level of students ' learning of knowledge and skills in the taught discipline;

- friendly and tactful with students;

- available for out-of-class communication on issues of educational and scientific information on consultations or remotely.

Students were asked to anonymously rate teachers on a 10-point system, according to which:

- $0-4.9$ points: unsatisfactory;

- 5.0-6.9 points: satisfactory;

- 7.0-8.5 points: well;

- Of 8.6-10.0 points: excellent.

The results of the survey of 1530 students were listed in the table (Table 1).

Table 1. A teacher through the eyes of students in 2018-2019 / 2019-2020 academic years.

\begin{tabular}{|c|c|c|c|c|c|c|c|c|c|c|}
\hline 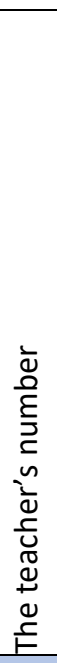 & 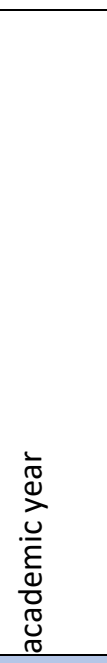 & 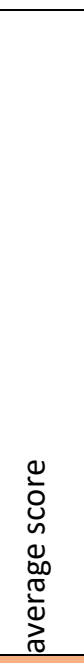 & 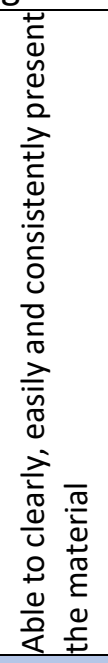 & 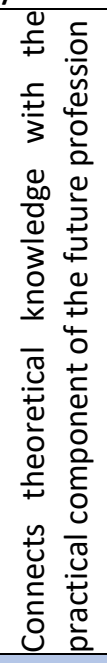 & 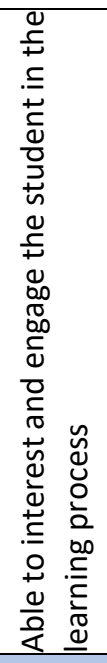 & 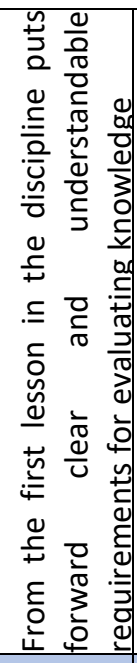 & 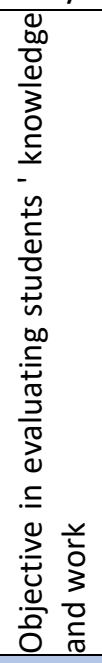 & 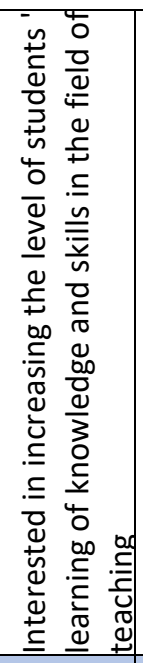 & 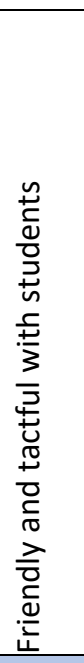 & 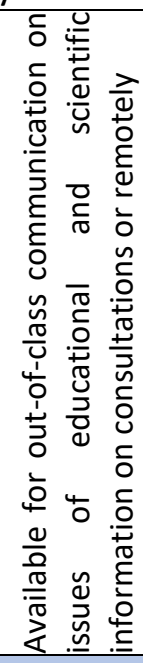 \\
\hline \multirow[t]{2}{*}{1.} & $\begin{array}{l}2018- \\
2019\end{array}$ & 8,85 & 9,61 & 8,83 & 9,28 & 8,44 & 8,56 & 8,94 & 8,61 & 8,50 \\
\hline & $\begin{array}{l}2019- \\
2020 \\
\end{array}$ & 9,11 & 9,06 & 8,72 & 8,72 & 9,00 & 9,06 & 9,19 & 9,69 & 9,47 \\
\hline \multirow[t]{2}{*}{2.} & $\begin{array}{l}2018- \\
2019\end{array}$ & 8,25 & 8,34 & 8,26 & 7,98 & 8,06 & 8,30 & 8,30 & 8,58 & 8,20 \\
\hline & $\begin{array}{l}2019- \\
2020\end{array}$ & 8,76 & 8,97 & 8,83 & 8,60 & 8,39 & 8,84 & 8,59 & 9,23 & 8,62 \\
\hline \multirow[t]{2}{*}{3.} & $\begin{array}{l}2018- \\
2019 \\
\end{array}$ & 9,20 & 9,33 & 8,75 & 9,00 & 9,17 & 8,33 & 10,00 & 9,75 & 9,25 \\
\hline & $\begin{array}{l}2019- \\
2020 \\
\end{array}$ & 9,43 & 9,44 & 9,33 & 9,35 & 9,40 & 9,42 & 9,39 & 9,55 & 9,54 \\
\hline \multirow[t]{2}{*}{4.} & $\begin{array}{l}2018- \\
2019 \\
\end{array}$ & 8,42 & 6,09 & 6,36 & 6,55 & 4,73 & 5,91 & 6,09 & 5,18 & 6,82 \\
\hline & $\begin{array}{l}2018- \\
2019 \\
\end{array}$ & 8,42 & 8,33 & 9,33 & 7,00 & 8,67 & 9,67 & 9,00 & 6,33 & 9,00 \\
\hline \multirow[t]{2}{*}{5.} & $\begin{array}{l}2018- \\
2019 \\
\end{array}$ & 8,47 & 9,04 & 9,00 & 8,36 & 7,86 & 8,14 & 9,04 & 8,89 & 7,43 \\
\hline & $\begin{array}{l}2019- \\
2020\end{array}$ & 8,89 & 9,05 & 9,30 & 9,00 & 8,90 & 8,65 & 9,35 & 8,15 & 8,75 \\
\hline \multirow[t]{2}{*}{6.} & $\begin{array}{l}2018- \\
2019 \\
\end{array}$ & 6,60 & 6,43 & 6,29 & 5,36 & 6,14 & 7,00 & 7,00 & 7,29 & 7,29 \\
\hline & $\begin{array}{l}2019- \\
2020\end{array}$ & 8,17 & 7,33 & 8,33 & 8,33 & 7,00 & 9,33 & 9,00 & 8,67 & 7,33 \\
\hline
\end{tabular}




\begin{tabular}{|c|c|c|c|c|c|c|c|c|c|c|}
\hline \multirow[t]{2}{*}{7.} & $\begin{array}{l}2018- \\
2019 \\
\end{array}$ & 9,52 & 9,38 & 9,63 & 9,50 & 9,50 & 9,50 & 9,63 & 9,63 & 9,38 \\
\hline & $\begin{array}{l}2019- \\
2020\end{array}$ & 9,36 & 9,44 & 9,51 & 9,39 & 9,17 & 9,22 & 9,44 & 9,31 & 9,42 \\
\hline \multirow[t]{2}{*}{8.} & $\begin{array}{l}2018- \\
2019 \\
\end{array}$ & 9,57 & 9,71 & 9,71 & 9,71 & 9,71 & 9,71 & 9,86 & 8,29 & 9,86 \\
\hline & $\begin{array}{l}2019- \\
2020\end{array}$ & 9,84 & 9,86 & 9,84 & 9,86 & 9,77 & 9,84 & 9,86 & 9,86 & 9,84 \\
\hline \multirow[t]{2}{*}{9.} & $\begin{array}{l}2018- \\
2019\end{array}$ & 6,40 & 7,00 & 7,00 & 6,20 & 5,40 & 5,40 & 7,40 & 6,60 & 6,20 \\
\hline & $\begin{array}{l}2019- \\
2020\end{array}$ & 8,58 & 8,68 & 8,59 & 7,50 & 8,61 & 9,05 & 8,68 & 8,70 & 8,84 \\
\hline \multirow[t]{2}{*}{10.} & $\begin{array}{l}2018- \\
2019 \\
\end{array}$ & 9,75 & 9,62 & 9,62 & 10,00 & 9,54 & 9,92 & 9,77 & 9,54 & 10,00 \\
\hline & $\begin{array}{l}2019- \\
2020\end{array}$ & 9,39 & 9,45 & 9,39 & 9,40 & 9,38 & 9,27 & 9,40 & 9,34 & 9,49 \\
\hline \multirow[t]{2}{*}{11.} & $\begin{array}{l}2018- \\
2019 \\
\end{array}$ & 6,21 & 6,64 & 6,82 & 5,86 & 5,82 & 5,82 & 6,50 & 6,64 & 5,59 \\
\hline & $\begin{array}{l}2019- \\
2020\end{array}$ & 8,20 & 8,43 & 7,93 & 7,60 & 8,03 & 8,07 & 8,57 & 8,17 & 8,80 \\
\hline \multirow[t]{2}{*}{12.} & $\begin{array}{l}2018- \\
2019\end{array}$ & 9,29 & 9,00 & 9,04 & 9,61 & 9,13 & 9,30 & 9,52 & 9,52 & 9,22 \\
\hline & $\begin{array}{l}2019- \\
2020 \\
\end{array}$ & 9,63 & 9,40 & 9,60 & 9,60 & 9,73 & 9,40 & 9,67 & 9,80 & 9,80 \\
\hline \multirow[t]{2}{*}{13.} & $\begin{array}{l}2018- \\
2019 \\
\end{array}$ & 6,50 & 8,00 & 6,33 & 6,67 & 5,67 & 6,33 & 7,00 & 5,67 & 6,33 \\
\hline & $\begin{array}{l}2019- \\
2020 \\
\end{array}$ & 7,98 & 8,10 & 7,80 & 7,71 & 7,92 & 7,86 & 8,14 & 8,14 & 8,14 \\
\hline \multirow[t]{2}{*}{14.} & $\begin{array}{l}2018- \\
2019 \\
\end{array}$ & 8,66 & 8,76 & 8,76 & 8,56 & 8,72 & 8,64 & 8,56 & 8,60 & 8,68 \\
\hline & $\begin{array}{l}2019- \\
2020 \\
\end{array}$ & 9,25 & 10,00 & 9,00 & 8,00 & 7,00 & 10,00 & 10,00 & 10,00 & 10,00 \\
\hline \multirow[t]{2}{*}{15.} & $\begin{array}{l}2018- \\
2019\end{array}$ & 8,69 & 9,50 & 9,00 & 8,75 & 8,50 & 7,75 & 8,75 & 8,75 & 8,50 \\
\hline & $\begin{array}{l}2019- \\
2020\end{array}$ & 9,69 & 9,75 & 9,63 & 9,69 & 9,63 & 9,78 & 9,69 & 9,75 & 9,59 \\
\hline \multirow[t]{2}{*}{16.} & $\begin{array}{l}2018- \\
2019\end{array}$ & 9,23 & 9,10 & 9,14 & 9,10 & 9,14 & 9,45 & 9,38 & 9,24 & 9,28 \\
\hline & $\begin{array}{l}2019- \\
2020 \\
\end{array}$ & 9,85 & 9,86 & 9,79 & 9,81 & 9,83 & 9,83 & 9,88 & 9,88 & 9,88 \\
\hline \multirow[t]{2}{*}{17.} & $\begin{array}{l}2018- \\
2019 \\
\end{array}$ & 9,05 & 9,07 & 8,95 & 9,15 & 9,15 & 8,88 & 8,93 & 9,00 & 9,27 \\
\hline & $\begin{array}{l}2019- \\
2020 \\
\end{array}$ & 9,52 & 9,55 & 9,39 & 9,33 & 9,55 & 9,55 & 9,47 & 9,63 & 9,65 \\
\hline \multirow[t]{2}{*}{18.} & $\begin{array}{l}2018- \\
2019 \\
\end{array}$ & 8,03 & 8,45 & 8,70 & 7,80 & 7,05 & 7,55 & 8,60 & 7,75 & 8,35 \\
\hline & $\begin{array}{l}2019- \\
2020 \\
\end{array}$ & 9,56 & 10,00 & 10,00 & 9,00 & 9,00 & 10,00 & 10,00 & 8,50 & 10,00 \\
\hline \multirow[t]{2}{*}{19.} & $\begin{array}{l}2018- \\
2019 \\
\end{array}$ & 8,81 & 10,00 & 9,00 & 9,00 & 7,00 & 8,50 & 8,00 & 9,50 & 9,50 \\
\hline & $\begin{array}{l}2019- \\
2020\end{array}$ & 9,63 & 9,50 & 9,71 & 9,52 & 9,54 & 9,67 & 9,65 & 9,85 & 9,63 \\
\hline \multirow[t]{2}{*}{20.} & $\begin{array}{l}2018- \\
2019 \\
\end{array}$ & 8,26 & 8,55 & 8,66 & 8,16 & 8,08 & 7,91 & 8,45 & 7,60 & 8,70 \\
\hline & $\begin{array}{l}2019- \\
2020\end{array}$ & 8,91 & 9,27 & 8,82 & 8,36 & 8,91 & 8,91 & 9,55 & 8,91 & 8,55 \\
\hline
\end{tabular}


Analysis of the survey showed that the ability of teachers to clearly, easily and consistently present the material has clearly increased. Students quite clearly note the improvement in the quality of teachers ' work $(4,6,9,11$,$) the rating of which has increased from "satisfactory" to$ "excellent".

For a financial University, where it is important to know the language of the future profession, a foreign language teacher must be able to link theoretical knowledge with the ability to apply it in a communicative business situation. The knowledge and competencies obtained from foreign specialists and methodologists have significantly improved the performance of a number of teachers $(4,6,9,11,13,14,18)$. This fact is probably due to the fact that the teachers, being trainees, from the position of students were able to master the knowledge they received and methodically competently, professionally choose a comfortable path of learning and teaching in each group.

Initially, students rated the ability of teachers to interest and involve students in the educational process quite highly, which indicates the personal motivation, professionalism and interest of our teachers, and the internship only improved these skills and competencies, enriching them with methodological techniques offered by foreign colleagues. In addition, this indicates a fairly strong domestic training of foreign language teachers in the field of methodology.

$85 \%$ of teachers more clearly and clearly put forward the requirements for the discipline from the first lesson, are more objective in assessing knowledge during class sessions, certifications and exams. This factor is due to clear criteria for evaluating each type of speech activity (listening, reading, speaking, writing), developed and applied by teachers of the Department, which greatly facilitates work with students. Awareness of the assessment criteria also allows students to independently assess their own knowledge and compare their" own " assessment with the teacher's assessment, evaluate the knowledge of their fellow students, and motivate them to be more demanding of themselves and the knowledge they receive in FL.

$80 \%$ of teachers have become more interested in improving the level of students ' knowledge and skills in the taught discipline, are more tactful and friendly with students, and $90 \%$ have become more accessible for extracurricular communication, including participation in international student conferences I, writing articles in international journals. This fact indicates that teachers, having become more confident in their knowledge of foreign languages, and having received a certain energy boost after obtaining country-specific knowledge and linguistic features, are more interested in teaching foreign languages. They become inquisitive researchers in search of methodological and linguistic techniques that will help students to stimulate and improve foreign language communication, included in the professional sphere. In this context, training becomes more practice-oriented, foreign language communicative professional competence is formed, which stimulates the motivation of students to study FL. The teacher himself is better and more freely oriented not only in his subject, but also in the field of direction and profile of training of his students, which improves classroom and extracurricular communication with them, encourages joint research in the FL. In addition, successful and effective classroom activities contribute to the emergence and implementation of new scientific and pedagogical ideas, which are reflected in the publication activity of teachers at the national and international level, thereby increasing the prestige of the University.

In general, we note that the average index of teachers for two academic years (2018-2019 / 2019-2020) has significantly increased. Let's describe it in the next histogram: 
Image 1. Average rating of teachers through the eyes of students for 2018-2019 / 2019-2020 academic years (SCORES)

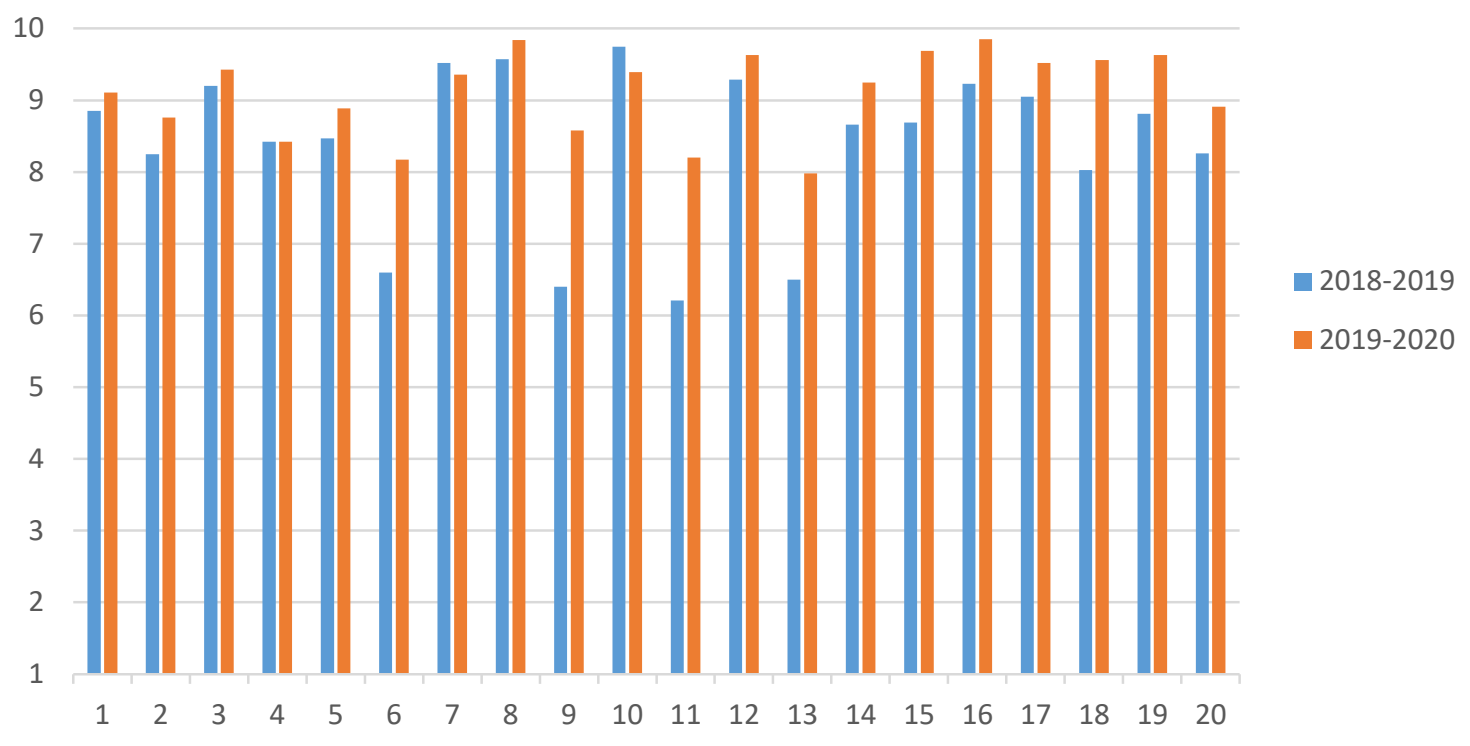

TEACHERS

It is obvious that students have a fairly high "excellent" rating of the work of the majority of teachers (55\%). However, there are also quite low "satisfactory" ratings (20\%) for the 2018-2019 academic year before passing the foreign internship. However, in the 2019-2020 academic year, after passing a summer internship abroad, there are significant improvements: the work of $80 \%$ of teachers is rated "excellent", $20 \%$ of teachers - "good". There is no "satisfactory" rating (Table 2).

Table 2. Comparative analysis of teachers ' assessment through the eyes of students according to the 5-point system

\begin{tabular}{|c|c|c|}
\hline Score & $\mathbf{2 0 1 8 - 2 0 1 9}$ & $\mathbf{2 0 1 9 - 2 0 2 0}$ \\
\hline Excellent & $11(55 \%)$ & $16(80 \%)$ \\
\hline Good & $5(25 \%)$ & $4(20 \%)$ \\
\hline Satisfactory & $4(20 \%)$ & - \\
\hline Poor & - & - \\
\hline
\end{tabular}

\section{CONCLUSION}

Therefore, due to foreign internship, the professional level of the teacher increases, mastering the culture of professional activity and linguistic culture as an integral part of the general culture of a modern person. The teacher's awareness of their place in the culture allows them to expand the range of their activities, encourages productive cooperation with students, contributing to their greater motivation to study the subject. An important result of the internship is to improve communication literacy, communication speech, increase communication culture, and develop communication skills. Despite the short duration, such internships help teachers to test their foreign language skills, plunge into a foreign language environment, assert themselves in their professional competence and start working with new enthusiasm in the new academic year.

Thus, passing a training abroad leads to the development and improvement of language, professional, and cultural competencies of not only teachers, but also students; improving the skills 
of teachers, their motivation; increasing not only the prestige of the educational organization, but also the publication activity of university employees in world scientific publications; improving educational technologies. And most importantly, students, as direct participants of the educational process, are more than satisfied with their results.

Authors' Contributions: Galina V. Tretyakova: conception and design, acquisition of data, analysis and interpretation of data, drafting the article, critical review of important intellectual content. Natalya V. Chernyishkova: conception and design, acquisition of data, analysis and interpretation of data, drafting the article, critical review of important intellectual content. Rosaria Filone: conception and design, acquisition of data, analysis and interpretation of data, drafting the article, critical review of important intellectual content. All authors have read and approved the final version of the manuscript.

Ethics Approval: Not applicable.

Acknowledgments: Not applicable.

\section{REFERENCES}

Ball, D. \& Cohen, D. (2009). Developing Practice, Developing Practitioners: Toward a Practice-based Theory of Professional Education. In the Heart of the Matter: Teaching as the Learning Profession. San Francisco: Jossey-Bass.

Borg, S. (2018). Evaluating the impact of professional development. RELC Journal, 49(2), 195-216.

Borko, H. (2014). Professional development and teacher learning: Mapping the terrain. Educational Researcher, 33(8), 3-15.

Boudersa, N. (2016). The Importance of Teachers' Training Programs and Professional Development in the Algerian Educational Context: Toward Informed and Effective Teaching Practices. Expériences Pédagogiques, 1, 1-14.

Cambridge Professional Development Qualifications. (2018). Retrieved from: http://www.cie.org.uk/cambridgeprofessional-development/professional-development-qualifications/

Darling-Hammond, L., Chung Wei, R., Andree, A., \& Richardson, N. (2019). Professional learning in the learning profession: A status report on teacher development in the United States and abroad. Oxford: National Staff Development Council.

Dufour, R., \& Eaker, R. (2008). Professional learning communities at work: Best practices for enhancing student achievement. Bloomington: Solution Tree.

Fullan, M.G. (2011). The New Meaning of Educational Change. New York: Teachers College.

Fullan, M.G., \& Miles, M. B. (2012). Getting Reform Right: What works and what doesn't. Phi Delta Kappan, pp. 745752.

Garet, M., Porter, A., Desimone, L., Birman, B., \& Yoon, K.S. (2011). What Makes Professional Development Effective? Results from a National Sample of Teachers. American Educational Research Journal, 38(4), 915-945.

Glattenhorn, A. (2017). Cooperative professional development: Peer centered options for teacher growth. Educational Leadership, 3(45), 31-35.

Guskey, T.R. (2010). Evaluating professional development. Thousand Oaks: Corwin Press.

Nascimento, L. F. do, \& Cavalcante, M. M. D. (2018). Abordagem quantitativa na pesquisa em educação: investigações no cotidiano escolar. Revista Tempos e Espaços em Educação, 11(25), 249-260.

Nystrand, M., \& Gamoran, A. (2011). Instructional discourse, student engagement, and literature achievement. Research in the Teaching of English, 25(3), 261-290.

Nzarirwehi, J. (2019). In-Service Teacher Training and Professional Development of Primary School Teachers in Uganda, IAFOR Journal of Education, 7(1), 19-36.

Oliveira, E. S., \& Barreto, D. A. B. (2020). Contemporary studies on knowledge, teaching in higher education and social representations in Brazil. Journal of Research and Knowledge Spreading, 1(1), e11585. 
Santos, I. T. R., Barreto, D. A. B., \& Soares, C. V. C. O. (2020). Formative assessment in the classroom: the dialogue between teachers and students. Journal of Research and Knowledge Spreading, 1(1), e11483.

Silva, F. O., Alves, I. S., \& Oliveira, L. C. (2020). Initial teaching training by homology in PIBID: experiential learning from professional practice. Journal of Research and Knowledge Spreading, 1(1), e11638.

Silva, C. V. S., \& Santos, G. O. (2020). Digital interfaces: a methodological proposal as a strategy of teaching and learning in Mathematics classes. Journal of Research and Knowledge Spreading, 1(1), e11651.

Richards, J.C., \& Farrel, T.S.C. (2012). Professional Development for Language Teachers: Strategies for Teacher Learning. Cambridge: Cambridge University Press.

Vu, P., Cao, V., Vu, L., \& Cepero, J. (2017). Factors driving learner success in online professional development. The International Review of Research in Open and Distance Learning, 15(3), 120-139.

Zaslow, M. (2014). General features of effective professional development. Preparing early childhood educators to teach math. Baltimore: Brookes Publishing.

Received: 10 October 2020 | Accepted: 12 January 2021 | Published: 22 January 2021

This is an Open Access article distributed under the terms of the Creative Commons Attribution License, which permits unrestricted use, distribution, and reproduction in any medium, provided the original work is properly cited. 